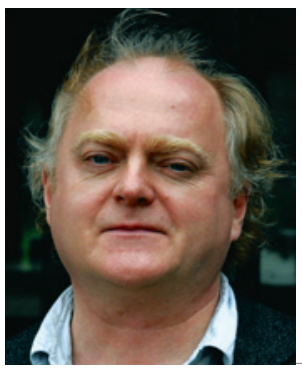

\title{
Legers plikt til å lyve
}

\author{
Mange litterære fremstillinger \\ iscenesetter språkets rolle i møtet \\ med sykdom.
}

Min tittel er antakelig like oppsiktsvekkende som den Ludvig Holberg (1684-1754) hadde i sin epistel nummer 381. Holberg likte ikke å skrive private brev og foretrakk såkalte kunstbrev, epistler, stilet til fiktive mottakere. Han utga samlinger av slike tekster i de siste seks årene av sin levetid. Flere epistler dreier seg om medisinske spørsmål, som Min helse og mine religiøse studier, Syfilis, spedalskhet og kopper, Innbildt sykdom er også sykdom (vi kunne kanskje føye til Bør man ha faste spisetider?) og altså den nevnte om leger og løgn.

Bakgrunnen for denne epistelen er en samtale han har hatt med en «Medicinæ Doctor» som var av den mening at man ikke skulle skåne pasienten for et nedslående budskap, med den begrunnelse at denne da kunne «berede sig til Døden, og giøre fornødne Anstalter for Bortrejsen». Holberg på sin side mener man må gå varsomt til verks og gi pasienten «et lidet Haab til Livet». For «Imaginationen hos Syge er stor» og den kan ha sterke virkninger. Forkynnelsen av en tung diagnose kan virke ytterligere negativt inn på den syke, mens det på den annen side finnes eksempler på at folk gjennom «Opmuntringer og undertiden ved Fictioner ere blevne curerede». Deretter kommer den lystige opplysningsmannen Holberg frem med et godt knippe eksempler på hvordan innbilt sykdom kan kureres, alle ved at legen tilsynelatende bygger opp rundt pasientens vrangforestillinger. Det viktige for polemikeren Holberg er at en «medicus» i visse tilfeller ikke bare kan - men også bør - skjule sannheten. Man kan mene hva man vil om dette, i dag er det vel ikke så lett å gi Holberg rett. Men ord er betydningsknuter, de kan ha uventet effekt.

For selv den friske kan det være helsebringende å lese Holberg. Skjønnlitteraturen kan for øvrig vise til inngående skildringer av hvordan ord og budskap om tunge diagnoser virker i sykdomssammenheng. I Georges Bernanos' hovedverk Journal d'un curé de campagne fra 1936. på norsk Underet i de tomme hender, får hovedpersonen, som er en enkel landsens prest, diagnosen magekreft. Scenen der legen hans forteller ham sannheten er rolig, men følelsene overfor ordlyden i diagnosen er opprivende: «Kreft ... Mavekreft ... Det var især ordet som forbauset meg. Jeg ventet et annet.»

I den sveitsiske forfatteren Fritz Zorns gripende selvbiografiske roman Mars fra 1977 spiller tvert om sykdommen en avgjørende, positiv rolle: «Kreften reddet mitt liv,» skriver Zorn, og tenker på hvordan den gjorde ham klar over hvor overfladisk hans liv til nå hadde vært. Et tredje litterært verk som problematiserer mottakelsen av en diagnose, er Lars Gustafssons En birøkters død fra 1978. Her velger den kreftrammede birøkteren Lars Westin å ikke åpne det avgjørende brevet fra sykehuset og heller leve sitt hverdagsliv som om ingenting har hendt. Men det har det jo, og boken, som er en fragmentroman der selve formen speiler den psykiske og fysiske oppløsningen romanfiguren gjennomgår, har intense beskrivelser av både smerte, hverdagslighet og eksistensiell tvil. Det overordnede temaet er den alternative holdningen til dødsbudskapet, en væren-til-døden som bryter med vanlig fornuft og som fremstår som en motvilje mot å bøye nakken for «keiseren over alle sykdommer», som Siddhartha Mukherjee kaller kreften.

For et tiår eller tre siden var det langt vanskeligere å snakke om kreft, skriver Erik Wist i 2002. Ordene «kreft» og «kreftavdeling» ble oppfattet som mer stigmatiserende enn faguttrykket «onkologisk avdeling». Romanforfattere var tidlig klar over dette aspektet, og Aleksander Solzjenitsyns roman Kreftavdelingen fra 1967 er et eksempel. Her utfoldes tematikk som politisk makt, håp, materialisme, $\mathrm{d} ø \mathrm{~d}$ og isolasjon i fortellingen om en gruppe kreftpasienter, alle innlagt på en avdeling som er et allegorisk bilde på det poststalinistiske sovjetrussiske samfunn. I dag virker romanen og tittelen antakelig mer historisk interessant enn opprørende.

Språket omkring sykdommen kreft er særlig viktig i Susan Sontags noe kontroversielle klassiker Sykdom som metafor. også den fra 1978. For Sontag var det om å gjøre å fjerne alt metaforisk innhold i omtalen av sykdom. Hun tar for seg tuberkulose og kreft, senere også aids, og det språket som innhyller vår forståelse av sykdom. Særlig er hun opptatt av alle de militære bildene vi bruker (krigen mot kreft, den indre fienden). Et slikt voldelig språk, mente hun, forverrer bare sykdommen. Nå viser hennes sønn, David Rieff, i erindringsboken Swimming in a sea of death at Sontag ikke selv hadde så lett for å akseptere skånselsløs medisinsk tale.

Problemet med ordenes virkning er dyptloddende.

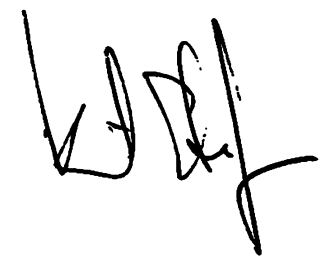

